\title{
Editorial
}

\section{Young Scientists and their Mentors}

We are pleased to publish the work of two young scientists in this issue of The Canadian Field-Naturalist. Adamo Young studied parasitoid wasps Diadegma insulare and Microplitis plutellae of the Diamondback Moth Plutella xylostella and Kiri Daust studied the impact of the Rust Puccinia linkii on Highbush Cranberry Viburnum edule. Both of these authors are Secondary School students, and both have won national awards for their work. As with any submission to The Canadian Field-Naturalist, these papers underwent the peer review process.

In corresponding with these two young scientists, it is immediately evident that they are self-motivated and enthusiastic about natural history and the pursuit of science. They both described years of recording observations and conducting investigations on natural history, and both have successfully competed in regional and national science fairs in Canada. Kiri described that participating in Science Fairs taught her to think analytically and to use science as a way of gaining knowledge about the world.

What is also evident is that both have benefitted from mentors. Dr. Peter Mason mentored Adamo in his lab at the Agriculture Canada Central Experimental
Farm. Peter introduced Adamo to biocontrol by introducing him to interactions between hosts and their parasitoids in the lab and the field. Peter taught Adamo the basics of science: how to identify a question, formulate a hypothesis, and conduct an experiment to verify or reject a hypothesis. Dr. Karen Price mentored Kiri in her observations in the field and throughout the analysis and write-up of her project.

Mentors play an instrumental role in the lives of young scientists. Good mentors are supportive of their students, but also willing to challenge ideas; they are approachable and patient; they are discerning in when to provide direction and when to allow the student to navigate his or her own way through a problem; they are observant and good listeners; and they exhibit a high level of enthusiasm for science. Good mentors help to make the process of doing science exciting. There is a long history of student mentoring among many of our natural history museums across Canada, and the Macoun Field Club, sponsored by the Ottawa Field Naturalists' Club, has been mentoring young naturalists for more than 50 years. This issue is dedicated to all of you who have helped to develop scientific investigating skills and to fan the flames of enthusiasm in young scientists. 